
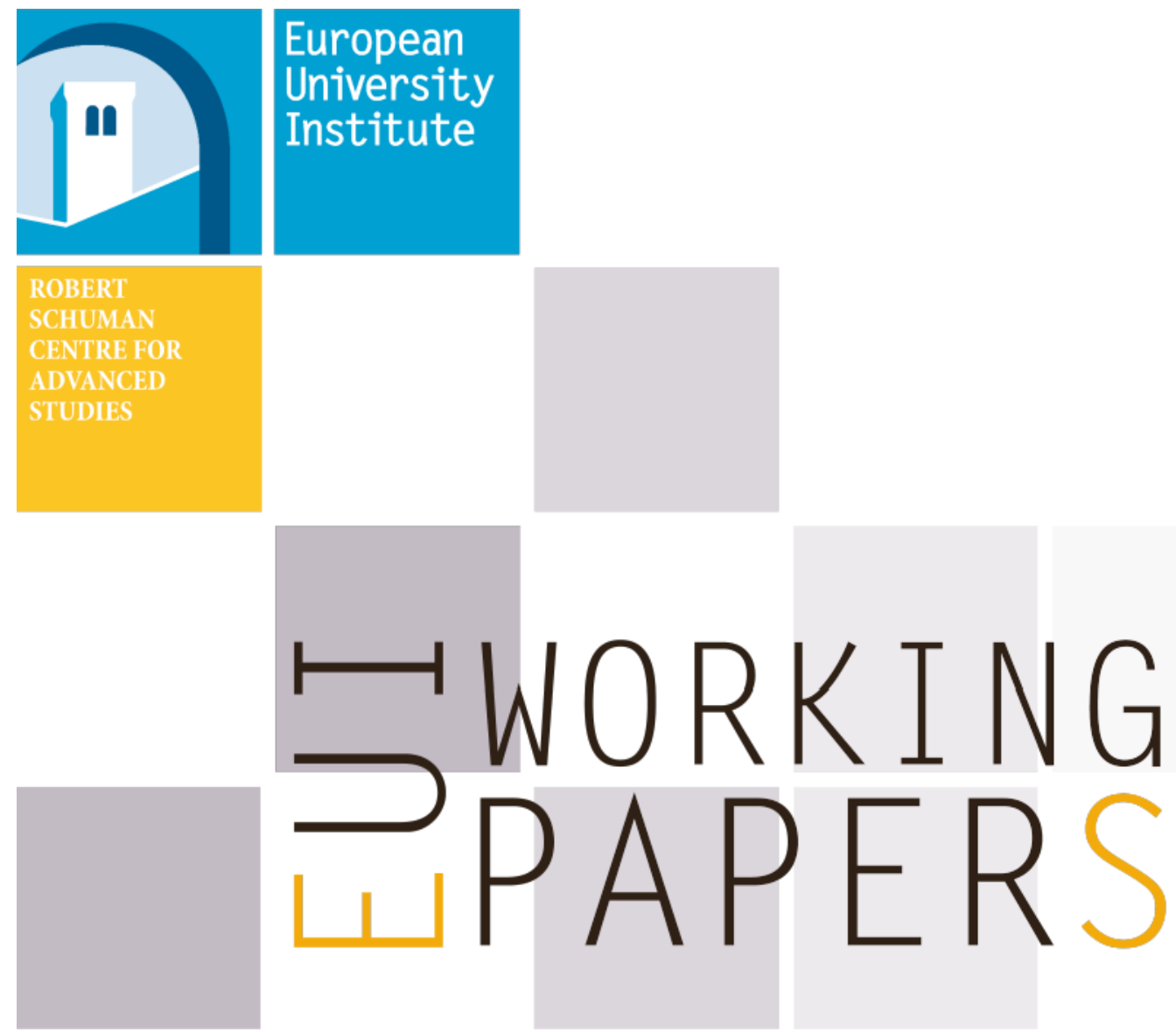

RSCAS 2016/46

Robert Schuman Centre for Advanced Studies Global Governance Programme-230

Services Policy Reform and Manufacturing Employment: Evidence from Transition Economies

Matteo Fiorini, Bernard Hoekman and Clément Malgouyres 

European University Institute

Robert Schuman Centre for Advanced Studies

Global Governance Programme

Services Policy Reform and Manufacturing Employment: Evidence from Transition Economies

Matteo Fiorini, Bernard Hoekman and Clément Malgouyres

EUI Working Paper RSCAS 2016/46 
This text may be downloaded only for personal research purposes. Additional reproduction for other purposes, whether in hard copies or electronically, requires the consent of the author(s), editor(s). If cited or quoted, reference should be made to the full name of the author(s), editor(s), the title, the working paper, or other series, the year and the publisher.

ISSN 1028-3625

(C) Matteo Fiorini, Bernard Hoekman and Clément Malgouyres, 2016

Printed in Italy, September 2016

European University Institute

Badia Fiesolana

I - 50014 San Domenico di Fiesole (FI)

Italy

www.eui.eu/RSCAS/Publications/

www.eui.eu

cadmus.eui.eu 


\section{Robert Schuman Centre for Advanced Studies}

The Robert Schuman Centre for Advanced Studies (RSCAS), created in 1992 and directed by Professor Brigid Laffan, aims to develop inter-disciplinary and comparative research on the major issues facing the process of European integration, European societies and Europe's place in $21^{\text {st }}$ century global politics.

The Centre is home to a large post-doctoral programme and hosts major research programmes, projects and data sets, in addition to a range of working groups and ad hoc initiatives. The research agenda is organised around a set of core themes and is continuously evolving, reflecting the changing agenda of European integration, the expanding membership of the European Union, developments in Europe's neighbourhood and the wider world.

Details of the research of the Centre can be found on: http://www.eui.eu/RSCAS/Research/

Research publications take the form of Working Papers, Policy Papers, and e-books. Most of these are also available on the RSCAS website:

http://www.eui.eu/RSCAS/Publications/

The EUI and the RSCAS are not responsible for the opinions expressed by the author(s).

\section{The Global Governance Programme at the EUI}

The Global Governance Programme is one of the flagship programmes of the Robert Schuman Centre for Advanced Studies at the European University Institute (EUI). It aims to: build a community of outstanding professors and scholars, produce high quality research and, engage with the world of practice through policy dialogue. At the Global Governance Programme, established and early career scholars research, write on and discuss, within and beyond academia, issues of global governance, focussing on four broad and interdisciplinary areas: European, Transnational and Global Governance; Global Economics; Europe in the World; and Cultural Pluralism.

The Programme also aims to contribute to the fostering of present and future generations of policy and decision makers through its unique executive training programme, the Academy of Global Governance, where theory and "real world" experience meet. At the Academy, executives, policy makers, diplomats, officials, private sector professionals and academics, have the opportunity to meet, share views and debate with leading academics, top-level officials, heads of international organisations and senior executives, on topical issues relating to governance.

For more information: http://globalgovernanceprogramme.eui.eu 



\title{
Services Policy Reform and \\ Manufacturing Employment: Evidence from Transition Economies*
}

\author{
Matteo Fiorini ${ }^{\dagger} \quad$ Bernard Hoekman ${ }^{\ddagger} \quad$ Clément Malgouyres ${ }^{\S}$
}

September 12, 2016

\begin{abstract}
The performance of services sectors can have significant impacts on industries that use services as intermediate inputs. In this paper we complement the literature analyzing the productivity effects of services trade policies by investigating the relationship between services policy reforms and employment in manufacturing industries. Using a panel of sector-level data for 24 transition economies for the 1990-2012 period, we find find that moving towards best practice services policies is associated with an economically significant reduction of manufacturing employment. This negative effect is mitigated or disappears for countries with high levels of economic governance and human capital. The decline in manufacturing employment is observed only in the first decade of transition, with the major driver being reforms in the utilities sector. The estimated negative effect of policy reforms is of a contemporaneous nature; it does not persist along the lag structure.
\end{abstract}

Keywords: services policy; employment; transition economies

JEL Classification: F16; F66; J23; P21

\section{Introduction}

The role of services in economic development has been attracting increasing attention. Examples include recent efforts to measure the share of value-added in traded goods that reflects embedded services, analysis of the trend towards servicification (manufacturing firms shifting to selling services as well as goods), and research on the determinants of structural transformation (the movement of workers and other factors of production from low to higher productivity activities). Structural transformation is usually characterized by an initial shift out of agriculture (employment in rural areas) into manufacturing (employment in urban areas), accompanied by a

\footnotetext{
${ }^{*}$ The authors are grateful to Andrea Ariu, Giuseppe Berlinghieri, Cosimo Beverelli, Francesco Bripi and Emmanuel Milet for helpful comments and conversations. We also thank participants at the Second Biennial conference on Empirical Investigations in Services Trade held at the EUI in June 2016. The views expressed here are those of the authors only and do not necessarily reflect the views of the Banque de France or the Eurosystem.

${ }^{\dagger}$ Global Governance Programme, Robert Schuman Centre for Advanced Studies (European University Institute). E-mail: matteo.fiorini@eui.eu.

${ }^{\ddagger}$ Global Governance Programme, Robert Schuman Centre for Advanced Studies and CEPR.

${ }^{\S}$ Banque de France.
} 
steady rise in the share of output and employment in services reflecting high income elasticities of demand for many services and a presumption that the productivity growth potential of many services sectors is limited.

A rapidly growing strand of the literature on services is concerned with the aggregate productivity effects of service sector performance. This has shown that services performance matters for firm-level competitiveness (productivity) in all sectors because many services are inputs into production, and many firms rely increasingly on a wide variety of service inputs that are sourced from outside suppliers. Of particular interest has been to better understand the effects of services policies on economic performance. There have been numerous empirical papers analyzing how services impact on economic performance and the effect of trade and other policies targeting service sectors on downstream productivity and/or export performance. ${ }^{1}$

Limited attention has been given to empirical assessment of how (changes in) services trade and investment and related regulatory policies impact on employment in manufacturing sectors. This paper seeks to partially fill this gap with a focus on the experience of transition economies, thereby contributing to the literature on structural transformation and to the analysis of the effects of service sector policies. The paper complements the extant literature on productivity effects of services policies as well as studies of the employment effects of services offshoring. The latter strand of the literature identifies different theoretical channels with ambiguous predictions regarding the effects of services offshoring on employment. On the one hand, offshoring lowers input prices and increases profits, in turn potentially increasing manufacturing production and labor demand. On the other hand, higher quality and cheaper service inputs may substitute for labor used in production, leading to a decrease in labor demand (Amiti and Wei, 2006; Milberg and Winkler, 2010b and Winkler, 2010).

Consistent with the theoretical ambiguity, the results of empirical analyses are mixed. Amiti and Wei (2005) find a positive correlation between services offshoring and employment in the UK between 1995 and 2001. Focusing on US sector-level data Amiti and Wei (2006) identify a negative effect of services offshoring on employment, using disaggregated data (450 sectors). This negative impact vanishes if a less disaggregated sector classification is used, suggesting that there is sufficient growth in labor demand in sub-sectors within these broader categories to offset the negative effect. In the case of Germany Schöller (2007) finds a negative impact of services offshoring on low-skilled labor in manufacturing sectors for the 1991-2000 period, as does Winkler (2010) for the period 1995-2006. Milberg and Winkler (2010a) and Milberg and Winkler (2015) extend this analysis to multi-country samples of OECD countries and show that negative impacts are attenuated by the existence of labor market institutions that reduce economic insecurity. ${ }^{2}$

In this paper we build on this literature to assess the effects of services-related policies on manufacturing employment for a panel of transition economies. Rather than focus on the impact

\footnotetext{
${ }^{1}$ Firm-level analyses of productivity effects include Arnold et al. (2008, 2011); Fernandes and Paunov (2011); Forlani (2012); Duggan et al. (2013); Bas (2014); Hoekman and Shepherd (2015) and Arnold et al. (2016). Studies using sector-level data include Barone and Cingano (2011); Bourlès et al. (2013) and Beverelli et al. (2015).

${ }^{2}$ Other research on the effect of services offshoring on productivity includes Görg and Hanley (2003) and Görg et al. (2008) working with plant-level data. Wright (2014) provides a theoretical analysis of the effect of (non services-specific) offshoring on employment. The structure and predictions of the model are in line with the services-specific mechanisms in the papers discussed in the text.
} 
of specific decisions by firms (offshoring), our interest is in the effects of services policies. In addition to analyzing the effects of services reforms, we extend the analysis of Milberg and Winkler (2010a) and Milberg and Winkler (2015) by investigating the role of economic governance (rule of law, control of corruption and regulatory quality) in moderating the employment effects of services policy reforms. We argue that the quality of economic governance, as opposed to more narrow measures of employment protection used in the offshoring literature, may shape the effect of services policy reforms by affecting incentives to invest and expand manufacturing output.

Our study also adds to the broader literature on the effect of reforms in transition economies and the question whether countries that pursued deeper reforms performed better than average. Studies on this subject mostly span country-level analysis, with mixed results regarding the effect of reforms on economic growth (see for instance the survey of empirical evidence in Falcetti et al., 2006). We make two contributions. First, in assessing the impacts of reforms we take into account differences in the intensity of use of different types of services inputs. Second, because we are able to exploit the heterogeneity across manufacturing industries, our empirical specification allows estimation under weaker identifying assumptions than most previous studies through countryyear fixed effects. This mitigates potential endogeneity problems that may arise, e.g., if reform implementation is a function of the state of the overall economy.

\section{Services reforms and employment in manufacturing}

The services reforms that are the focus of analysis in what follows are pro-competitive in nature, comprising reductions in restrictions on international trade and inward foreign direct investment (FDI), the removal of barriers to entry for private firms and more generally the introduction of commercial freedoms, and actions to establish or strengthen regulatory regimes and implementing institutions. The policy indicators we use have been developed by the European Bank for Reconstruction and Development (EBRD), and measure the distance between prevailing policies in a given year with what is deemed to constitute good (best) practice. They are unique in being available on an annual basis starting in $1990 .^{3}$

Other things equal, movement in the direction of better economic governance and regulatory practices is expected to result in lower prices, higher quality and/or greater variety in the availability of producer services. Assuming this is the case, reforms may impact on manufacturing employment through different potential channels. Improved access to cheaper or higher quality services inputs may increase profits. Higher profit margins, in turn, may result in an expansion in the scale of production, through lower output prices or higher investment. Such a price-induced positive scale effect is likely to be associated with an increase in labor demand of the downstream sectors.

Alternatively, access to more efficient and technologically-advanced producer services may permit specialization by manufacturing firms in core activities. This may lead to an expansion of

\footnotetext{
${ }^{3}$ A detailed description of the sector-specific policy and institutional indicators reported in the EBRD Transition Indicators Database is provided in Appendix C.
} 
manufacturing production, but have ambiguous effects on manufacturing employment. Greater output may require more production workers, but if greater specialization entails outsourcing of non-core services activities, overall employment in manufacturing may decline. In this case there will be a reallocation of services workers across sectors, with ambiguous results as far as overall employment in downstream manufacturing industries is concerned. ${ }^{4}$ Reforms that involve the removal of services trade barriers may also lead to services offshoring in addition to domestic outsourcing. If so, there might be direct replacement of domestic workers providing services (whether in-house or by specialized services firms) by more efficient or less expensive foreign workers employed abroad. ${ }^{5}$ The upshot is that the net effect on manufacturing employment is unclear.

An additional complication that is specific to the transition context is that in the early years of economic reform changes in policies that led to hard budget constraints and cost-reflective pricesetting could lead to increases in prices of services inputs. If price controls and more generally non-market-based allocation of resources under central planning led to under-pricing of services inputs, the transition process will lead to increasing prices for such inputs to reflect their real market value. This was the case for energy services in many transition economies, which often was effectively subsidized for major manufacturing industries under central planning. Insofar as the initial years of transition were accompanied by increases in input costs for manufacturing industries that could not be passed on to customers, policy reforms would tend to increase costs, with a negative effect on output and employment. Moreover, pro-competitive reforms had the effect of disrupting long-established supply networks and contractual relationships between manufacturing plants and their suppliers (Roland and Verdier, 1999) reducing the contemporaneous efficiency gains of reforms. There are of course other transition-specific factors as well, including political economy forces, see for example BenYishay and Grosjean (2014).

We abstract from the specific dimensions of the transition process in this paper. What matters for our analysis is that there are idiosyncratic factors that influence the employment effects of policy reforms undertaken in our sample of Eastern European and Central Asian (EECA) transition economies that will not be observed in market economies. The most important of these factors is that in transition countries policy reforms occurred in a setting where domestic services sectors were rather embryonic and/or stagnant. The share of services in GDP was invariably substantially below that observed in market-based economies with similar levels of industrial development, educational attainment and technical capacity. Reforms to open the economy, remove price and other controls and to permit entry into services activities triggered a rapid expansion of service industries with an associated increase in demand for workers in services sectors. Figure 1 illustrates this feature of the transition process. In the early 1990s the share of services in total employment in our sample was around $35 \%$, as opposed to $60 \%$ on average in OECD member countries. During the two subsequent decades the share of services in total employment increased by $70 \%$ in our sample, as opposed to only $15 \%$ in OECD countries.

\footnotetext{
${ }^{4}$ For a model of these types of effects see Francois (1990).

${ }^{5}$ These and similar effects have been discussed by Amiti and Wei $(2005,2006)$ and Winkler (2010).

6 'EECA sample' refers to the 24 countries in the Eastern Europe and Central Asia region covered in our empirical analysis. See Appendix A for a complete list of such countries. The employment share (\% of total population) series are from the World Bank World Development Indicators. 'OECD countries' refers the the
} 
Figure 1: Services and manufacturing employment shares. ${ }^{6}$

EECA sample

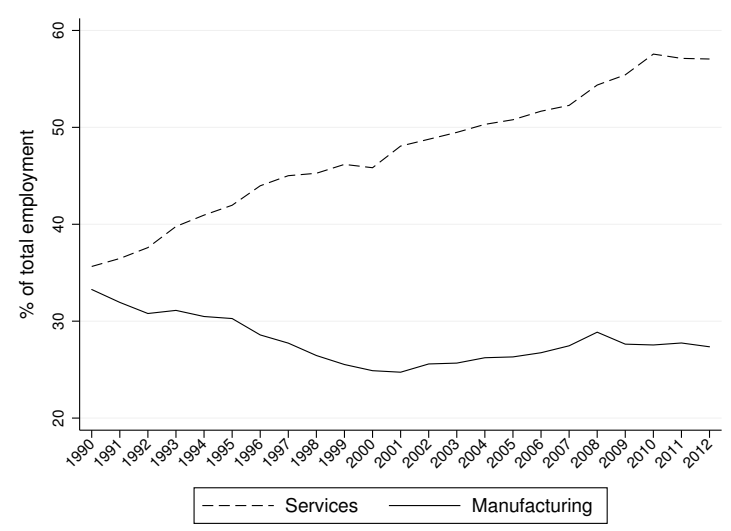

OECD Countries

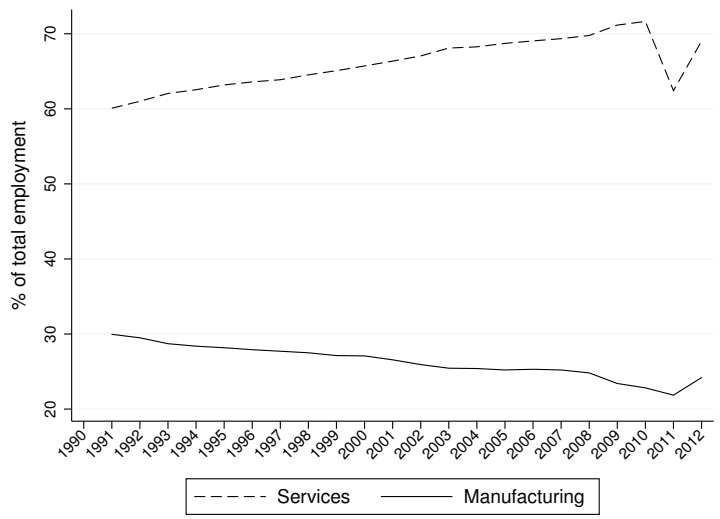

Clearly an increase in overall employment in services sectors was a basic feature of the transition process, reflecting a mix of new entry and investment in services activities and incentives for manufacturing industries to improve efficiency by outsourcing services. Our interest in what follows is the effect of services policy reforms on downstream manufacturing employment. While there are good reasons to expect this to be negative in the initial period of economic transition, it is possible that manufacturing employment could expand as a result of access to cheaper and better services inputs following reforms. Conversely, outsourcing of services could lead to a net reduction in manufacturing employment, complementing transition-specific factors that put pressure on manufacturing employment. Thus, the net effect of services reforms on downstream employment is essentially an empirical matter.

\section{Empirical model}

To estimate the impact of services policy reforms on manufacturing employment we follow an empirical methodology in the spirit of Rajan and Zingales (1998), who postulate that the degree of financial dependence across sectors mediates the effect of national financial policies on value added growth at the sector level. Analogously we posit that the effect of upstream services reforms on downstream employment is a function of downstream sectors' use of services inputs. Consistent with this, we interact services policy indicators that vary at the time and country level with measures of services input intensity that are manufacturing sector-specific. Summing across services sectors we obtain a composite reform indicator that varies at the country $c$, manufacturing sector $i$ and time $t$ level. This indicator - that is going to be the regressor of interest in our model - is specified in the following formula

$$
C R E F_{c i t}=\sum_{s} R E F_{s c t} \times w_{s c i t}
$$

World Bank aggregate which covers all OECD economies. 
where $R E F_{\text {sct }}$ is the policy variable for services sector $s$ in country $c$ and $w_{\text {scit }}$ is the measure of input intensity of services $s$ into manufacturing sector $i$ in country $c$. For the latter we use standard input-output technical coefficients. Finally we normalize the composite indicator to vary between 0 and 1 and we denote the normalized version by cref $_{\text {cit }}$.

This approach allows us to employ an exhaustive battery of fixed effects. Our baseline employment specification is given by the following equation:

$$
l_{c i t}=\beta c r e f_{c i t}+\zeta_{c i}+\eta_{c t}+\theta_{i t}+\epsilon_{c i t}
$$

where $l_{c i t}$ is the natural logarithm of employment in country $c$ and manufacturing sector $i$ at time $t$. While particularly demanding on the data, this specification controls for any observed or unobserved heterogeneity at the country-sector $\left(\zeta_{c i}\right)$, country-time $\left(\eta_{c t}\right)$ and sector-time $\left(\theta_{i t}\right)$ level. In particular, the model accounts for many of the determinants of employment which are normally used in empirical studies of industry labor demand (Amiti and Wei, 2005, Amiti and Wei, 2006 and Winkler, 2010). Indeed, shocks to a particular country or sector at any point in time that affect the supply of labor, the price of intermediate inputs (including wages), output volumes and production technologies are subsumed in the country-time and industry-time fixed effects. On top of this, the country-sector fixed effects absorb all the time invariant characteristics that are idiosyncratic to each single country-sector pair including country-specific endowments which affect the underlying long-run labor intensity of a country's sectors and, in turn, their employment levels.

Following Blonigen (2015), we first-difference the data by country-sector to control for countrysector fixed effects, as well as to mitigate time-series issues. ${ }^{7}$ As a result we estimate the empirical model specified in the following equation:

$$
l_{c i t}-l_{c i(t-1)}=\beta\left[\operatorname{cref}_{c i t}-\operatorname{cref}_{c i(t-1)}\right]+\lambda_{c t}+\mu_{i t}+\varepsilon_{c i t}
$$

There are several endogeneity concerns that need to be addressed. First, empirical studies adopting the difference-in-differences methodology pioneered by Rajan and Zingales (1998) need to avoid the use of country specific input intensity measures becasue services input intensities in downstream sectors are likely to depend on services regulation itself (the policy treatment). Moreover, an industrial strategy aiming at employment expansion could potentially imply the reduction of services outsourcing to boost in house activities. This would cause a problem of reverse causation from employment levels to the input-output component of our regressor of interest. The most widely adopted solution to these types of problems is to use a reference country as a unique source of input-output data, with the underlying assumption that the inputoutput linkages in the reference country are a good proxy for technological relationships between sectors. $^{8}$ We adopt this standard approach, computing technical coefficients from the mid-1990s input-output matrix of the United States. We show in Section 5.6 that our results are robust to

\footnotetext{
${ }^{7}$ We estimate standard errors clustered at the country-sector level to make them robust to any remaining autocorrelation.

${ }^{8}$ Examples of relevant papers that adopt and discuss this solution are Rajan and Zingales (1998), Barone and Cingano (2011), Bourlès et al. (2013) and Beverelli et al. (2015).
} 
using country-specific coefficients.

Secondly, no fixed-effect solution is available for heterogeneity that has a country-sector-year nature and that could drive the relationship between employment in manufacturing and the policies affecting the services sectors. Two potential sources of omitted variable bias are output and wages. These variables are standard determinants of sectoral labor demand (a component of our depend variable) and they are likely to reflect shocks that are not only country-time or sector-time specific (as is the case for other determinants of labor demand as prices or technology shifters). Additionally they may be correlated with policy reforms in the services sector which can potentially affect the scale (output) and the labor skill composition (wages) in manufacturing industries. In order to account for omitted variable sources of endogeneity we augment the baseline specification with controls capturing the value of output and individual wages at the country, sector and time level.

Finally, a potential source of reverse causation is lobbying behavior, which may result in linkages between employment in manufacturing sectors and the policy component of our regressor of interest. In principle employment may in part reflect the incentives of a given industry in a country/time period to lobby for policy reforms in the services sector. In a similar empirical framework to the one used here, Beverelli et al. (2015) use an instrumental variable approach to show that this potential source of endogeneity is weak and gives rise to negligible estimation biases when the dependent variable is a measure of productivity. In any event, we believe that lobbying incentives are more likely to be fixed in the short-run, reflecting long-standing relationships between the sectors and the political system. While this argument is less compelling in the case of our sample of transition economies, time varying shocks that originate from changes in the political system are captured by the country-time fixed effects.

\section{Data}

We use three distinct sources of information to construct the variables of our baseline specification (equation 3.2): (i) data on employment and other manufacturing sectors outcomes; (ii) measures of service sector policy reforms; and (iii) measures of the degree to which different manufacturing sectors source from the service sectors for which policies are being reformed.

The dependent variable (employment) comes from the UNIDO Industrial Statistics. This dataset contains information on output, value added, employment and wages for about 20 manufacturing industries per country. We also compute a measure of total factor productivity using this database. ${ }^{9}$

The key independent variable of interest (denoted as cref) combines service sector reform indicators with input-output coefficients. The I-O coefficients are obtained from the OECD STAN

\footnotetext{
${ }^{9}$ Output and value added per worker are expressed in nominal terms (current US dollars). Note however that given that we include sector-year fixed effect we absorb sector-specific changes in prices to the extent that they are uniform across countries. This appears like a reasonable assumption considering the tradable nature of the manufacturing sector output. For a similar argument see Rodrik (2013). Our results are robust to the use of deflated series.
} 
input-output tables. Unless stated otherwise, we use the mid-1990s US input-output table to compute the weights for all countries (i.e. we assume $w_{\text {scit }}=w_{s, U S, i, m i d 90 s}$ for all countries $c$ ). As discussed in Section 3, this practice is widespread in the literature following Rajan and Zingales (1998). It is motivated by concerns regarding the endogeneity of weights with respect to domestic regulations, and a presumption that the United States economy is relatively undistorted so that its input-output coefficients are more likely to reflect technological properties of different manufacturing industries as opposed to the distortive effect of specific service regulations.

The indicators of service reforms are constructed by the EBRD, which has compiled these on an annual basis since 1989. The indicators are designed to monitor progress in policy reform in transition economies. They span a number of service sectors: financial services (banking and non-banking), transport (railways, roads), utilities (water, electricity) and telecommunications. The indicators take a value ranging between 1 (no progress since 1989) to 4.3 (adoption of best practices comparable to advanced OECD economies). From this database we construct policy reform indicators for four services industries, finance, telecommunications, transport and utilities. $^{10}$

The left panel of Figure 4 displays the simple average policy index across the four service sectors and shows substantial variation in the pace of reforms across the 24 countries included in the estimation sample. While all countries started with similar scores in 1990, some countries such as Hungary, Poland or Estonia implemented rapid reforms during the 1990s while others such as Belarus and Ukraine undertook much more modest reforms. On average it appears that most reforms were implemented during the 1990s, with much more more limited improvements achieved during the 2000s.

Figure 4: Regulation over time and across countries. ${ }^{11}$

Simple average of reform indicators across sectors

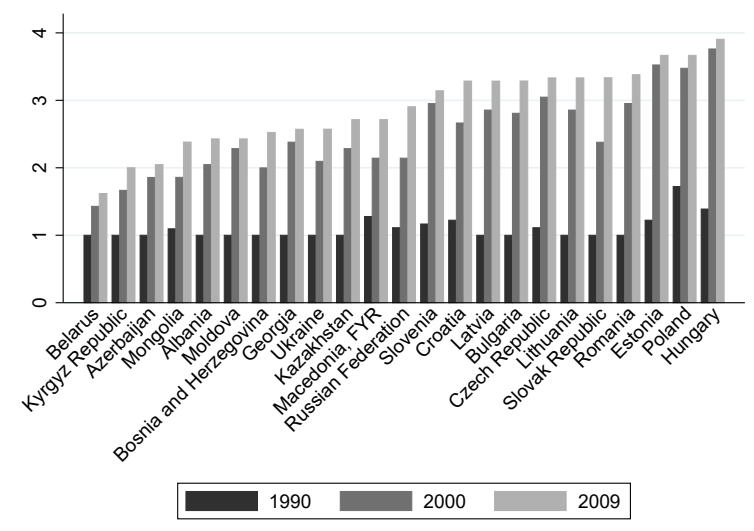

Dispersion (standard deviation) of reform indicators across sectors

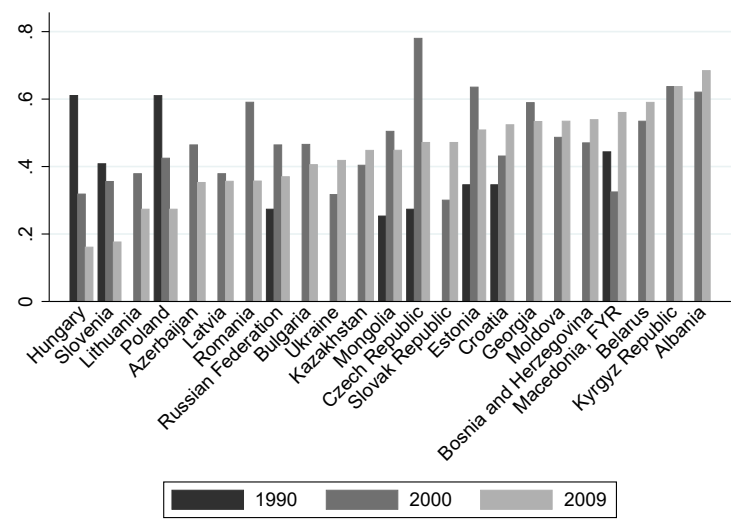

In addition to the cross-country variation in the pace and depth of reforms, countries also exhibit substantial cross-sector variation. This is evident from the right-hand panel in Figure 4, which reports the standard deviation of the reform indicators across sectors for each country for three

\footnotetext{
${ }^{10}$ Details on the EBRD raw data as well as on the construction of the services specific indicators used in our analysis are provided in Appendix C.
} 
different years (note that the standard deviation is zero for many countries in 1990, a year at which reforms toward a market economy had barely begun for most economies).

Table 1 reports the average annual growth rate in employment across all sample countries for each sector. While overall employment in manufacturing has declined (as is evident from Figure 1 above), there is a lot of variation across industries within manufacturing. The table confirms the fact that decline in employment was much stronger during the 1990s than the 2000s. We see for instance that the motor vehicle industry shrank at a $9 \%$ a year during the 1990s but grew positively over the $2000-2012$ period.

Table 1: Average annual growth rate by sector

\begin{tabular}{lrrr}
\hline Period: & 1990-2012 & $1990-1999$ & $2000-2012$ \\
\hline Basic metals & -2.74 & -3.91 & -1.91 \\
Chemicals & -3.95 & -4.94 & -3.16 \\
Coke, refined petroleum & -1.72 & -0.47 & -2.85 \\
Communication & -0.8 & 1.27 & -1.71 \\
Electrical machinery & -3.28 & -8.75 & 0.41 \\
Fabricated metal products & -1.07 & -7.65 & 2.99 \\
Food, beverages & -1.64 & -1.82 & -1.52 \\
Machinery and equipment & -6.6 & -8.43 & -4.88 \\
Motor vehicles, trailers & -4.29 & -9.12 & 1.06 \\
Other mgf and recycling & -4.13 & -9.61 & -0.01 \\
Other non-metallic prod. & -4.75 & -7.78 & -2.36 \\
Other transport equipment & 0.73 & 2.82 & 0.47 \\
Precision instruments & -5.41 & -14.94 & 0.79 \\
Pulp, paper & -0.35 & 0.08 & -0.56 \\
Rubber and plastic products & 1.17 & -3.87 & 3.43 \\
Textiles & -6.5 & -7.41 & -5.55 \\
Wood products & -2.85 & -1.98 & -3.36 \\
\hline Across sectors & -3.43 & -6.12 & -1.44 \\
\hline Notes: Based on the estimating sample corresponding to 5,500 (sector-country-year) \\
observations in 24 countries and 18 sectors over 23 years (1990-2012). Growth rates \\
computed weighing observations based on their initial employment. & \\
& & &
\end{tabular}

Table 2 reports the mean and standard deviations of the key dependent and explanatory variables for our estimating sample, both in levels and in first-differences (thus reflecting more accurately the variation we exploit to estimate our model). 
Table 2: Descriptive statistics for dependent variable and main independent variable in firstdifferences

\begin{tabular}{|c|c|c|c|c|}
\hline Variable & Mean & Std Deviation & Minimum & Maximum \\
\hline$l_{\text {cit }}$ & 9.500 & 2.009 & 0.693 & 14.780 \\
\hline cref $_{\text {cit }}$ & 0.261 & 0.176 & 0 & 1 \\
\hline $\log$ output $_{\text {cit }}$ & 19.548 & 2.636 & 8.889 & 26.001 \\
\hline log wages cit & 7.923 & 1.258 & -1.435 & 10.698 \\
\hline \multicolumn{5}{|c|}{ Var in first diff } \\
\hline$l_{c i t}$ & -0.025 & 0.301 & -3.989 & 3.332 \\
\hline cref $_{\text {cit }}$ & 0.010 & 0.019 & -0.067 & 0.251 \\
\hline log output ${ }_{c i t}$ & 0.088 & 0.546 & -3.601 & 6.185 \\
\hline log wages ${ }_{c i t}$ & 0.099 & 0.466 & -5.618 & 5.963 \\
\hline
\end{tabular}

\section{Results}

\subsection{Main estimation results}

Results for the estimation of our baseline model are given in the first column of Table 3. The coefficient for cref shows that services policy reforms have a negative and statistically significant effect on downstream employment. This result holds true - with minor changes in magnitude and within the standard levels of statistical significance - when the specification is augmented with the $\log$ of output (column 2), the $\log$ of individual wages (column 3) or both (column 4). Note that in these cases the signs of the coefficients for output and wages are consistent with the standard empirical results on labor demand, which is positively associated with production and negatively associated with the cost of labor.

Table 3: Effect of services reform on manufacturing employment

\begin{tabular}{|c|c|c|c|c|c|c|}
\hline & \multicolumn{6}{|c|}{ Dep var: log employment } \\
\hline & (1) & (2) & $(3)$ & (4) & (5) & (6) \\
\hline cref & $\begin{array}{l}-0.965^{* *} \\
(0.481)\end{array}$ & $\begin{array}{l}-0.952^{* *} \\
(0.457)\end{array}$ & $\begin{array}{l}-0.931^{*} \\
(0.489)\end{array}$ & $\begin{array}{l}-0.863^{*} \\
(0.470)\end{array}$ & $\begin{array}{l}-1.695^{* * *} \\
(0.600)\end{array}$ & $\begin{array}{l}-1.887^{* * *} \\
(0.679)\end{array}$ \\
\hline $\log$ output & & $\begin{array}{c}0.342^{* * *} \\
(0.0376)\end{array}$ & & $\begin{array}{c}0.418^{* * *} \\
(0.0311)\end{array}$ & $\begin{array}{c}0.483^{* * *} \\
(0.0392)\end{array}$ & $\begin{array}{c}0.451^{* * *} \\
(0.0452)\end{array}$ \\
\hline log wages & & & $\begin{array}{l}-0.132^{* * *} \\
(0.0426)\end{array}$ & $\begin{array}{l}-0.328^{* * *} \\
(0.0543)\end{array}$ & $\begin{array}{l}-0.235^{* * *} \\
(0.0477)\end{array}$ & $\begin{array}{l}-0.225^{* * *} \\
(0.0514)\end{array}$ \\
\hline $\log$ imports & & & & & $\begin{array}{l}-0.0221 \\
(0.0200)\end{array}$ & $\begin{array}{c}-0.00969 \\
(0.0231)\end{array}$ \\
\hline Observations & 5500 & 5500 & 5500 & 5500 & 4449 & 3222 \\
\hline Adjusted $R^{2}$ & 0.135 & 0.327 & 0.149 & 0.405 & 0.442 & 0.402 \\
\hline Year coverage & 1990-2012 & 1990-2012 & 1990-2012 & 1990-2012 & 1990-2012 & 1990-2007 \\
\hline
\end{tabular}


As a robustness check, in the last two models reported in Table 3 we augment our preferred specification of column 4 with imports at the manufacturing sector-country-year level. ${ }^{12}$ This additional control is chosen to capture policy reforms that vary across downstream manufacturing sectors, countries and years. Absent any specific data source for manufacturing sector-specific reforms for our sample, we use trade developments as a proxy for the more general pattern of reforms across manufacturing sectors. Given that the structure of import protection implemented by transition economies under central planning involved extensive use of exchange controls, FX rationing and quotas as opposed to tariffs, and the limited tariff data availability for the early transition period, we use import supply (an outcome measure) as a proxy for applied trade policy in our estimation sample. Note that limited trade data coverage at the industry level, even though more widely available than tariff protection data, results in a reduction in the estimation sample of approximately $20 \%$ (see column 5). Column 6 further controls for the sector-country-yearspecific policy responses to the global financial crisis by removing the years 2008-2012 from the estimation sample. In both cases the negative sign of the coefficient for the regressor of interest is maintained. The magnitude (in negative terms) as well as the statistical significance of the estimates increase, ${ }^{13}$ confirming our preference for model 4 as generating conservative estimates while maximising the size of the estimation sample.

To provide a sense of the economic meaning of our estimates we use the results from our preferred specification in column (4) to quantitatively assess the employment effect of a pro-competitive policy change consisting in a one standard deviation increase in each services sector-specific policy reform index. The downstream effect of a policy shift depends upon the input intensity coefficients and therefore is specific to each manufacturing sector $i$. Given that our dependent variable is expressed in logs, the percentage change in manufacturing sector $i^{\prime} s$ employment level resulting from a one standard deviation increase in all services policy measures is computed as:

$$
\% \Delta L_{i}=-0.863 \times 100 \times \Delta \text { cref }_{i}
$$

where $L$ denotes employment without the $\log$ transformation and $\Delta c r e f_{i}$ is the normalized version of $\triangle C R E F_{i}=\sum_{s}\left(\sigma_{s} \times w_{s i}\right)$, with $\sigma_{s}$ being a standard deviation in the distribution of sector $s$ policy measures. ${ }^{14}$ Standard deviations are computed for the country-year pairs in the estimation sample of Table 3. They are equal to 0.73 for finance and insurance; 0.94 for telecommunications; 0.75 for transport services; and 0.84 for utilities. These variations represent very common occurrences in our sample. All countries undergo changes of a one standard deviation in their reform indicators in all sectors at least once; 11 countries out of 24 go through reforms of twice

\footnotetext{
${ }^{12}$ Import data are from the World Bank WITS database (see Table A-1 in Appendix A). Given the use of country-time and sector-time fixed effects in the estimation there is no need to correct the import values expressed in absolute terms - by scaling them with country or sector level characteristics varying across time.

${ }^{13}$ Given that the estimated coefficients for the log of imports are not statistically significant, the increase in the magnitude and statistical significance of the cref coefficients may be largely driven by the changes in the estimation sample.

${ }^{14}$ In order to derive $\Delta c r e f_{i}$ we proceed as follows. First we compute $C R E F_{c i t}^{\sigma}=\sum_{s}\left(R E F_{s c t}+\sigma_{s}\right) \times w_{s i}$. As in the case of $C R E F$, the input-output technical coefficients are taken from a reference country (the US) and a reference period (mid 90s). Then we normalise this quantity using the minimum and maximum value of $C R E F_{\text {cit }}$ to obtain $c r e f_{c i t}^{\sigma}$. Finally we subtract $c r e f_{c i t}$ from $c_{r e f}^{\sigma}{ }_{c i t}^{\sigma}$. The resulting difference, denoted by $\Delta c r e f_{i}$ varies only at the manufacturing sector level and represents - in the normalised scale of $c r e f_{i}$ - the increase by one standard deviation in the policy reform variables.
} 
this magnitude. Standing out in the sample, Czech Republic and Estonia implemented reforms of 3 times this magnitude.

As shown in Table 4, the employment effect of the hypothesised reform results in a $-4.16 \%$ decline in the downstream sector with the lowest average services input intensity (manufacturing of office, accounting and computer machinery). The policy change is associated with a $-18.90 \%$ reduction in employment level for the downstream sector with the highest average requirement of services intermediates (manufacturing of non-metallic mineral products).

Table 4: Effect of one standard deviation increase in the reform indicator by manufacturing sector

\begin{tabular}{ll}
\hline Manufacturing sector (ISIC rev.3) & $\% \Delta L$ \\
\hline Office, accounting and computing machinery (30) & -4.16 \\
Radio, television and communication equipment (32) & -4.63 \\
Medical, precision and optical instruments (33) & -5.41 \\
Other transport equipment (35) & -5.92 \\
Electrical machinery and apparatus n.e.c (31) & -6.01 \\
Motor vehicles, trailers and semi-trailers (34) & -6.17 \\
Machinery and equipment n.e.c (29) & -6.30 \\
Food products, beverages and tobacco (15,16) & -6.89 \\
Manufacturing n.e.c; recycling (36,37) & -6.94 \\
Textiles, textile products, leather and footwear (17-19) & -7.02 \\
Fabricated metal products except machinery and equipment $(28)$ & -7.69 \\
Wood and products of wood and cork (20) & -8.20 \\
Pulp, paper, paper products, printing and publishing (21,22) & -9.58 \\
Rubber and plastics products (25) & -11.13 \\
Chemicals and chemical products (24) & -11.25 \\
Basic metals (27) & -12.92 \\
Coke, refined petroleum products and nuclear fuel (23) & -18.53 \\
Other non-metallic mineral products (26) & -18.90 \\
\hline
\end{tabular}

Notes: ISIC rev.3, 2 digits classification in parenthesis.

\subsection{Heterogeneous effects across country groups and time periods}

\subsubsection{Economic governance and human capital}

We now exploit the country-level heterogeneity in our sample to analyze whether and how the negative effect found in Section 5.1 changes when computed over subsamples defined in terms of relevant country-level characteristics. In particular we are interested in investigating the role of broad indicators of economic governance as well as human capital at the country level in influencing the downstream employment impacts of services policy reforms.

In principle, the role of governance institutions in shaping the employment effect of services reforms is ambiguous. On the one hand good institutions (high regulatory quality, control of corruption and rule of law) may support more rapid firm level adjustment to policy reforms. Good institutions can allow firms to substitute in-house activities with more efficient services coming from a reformed sector, minimising rigidities due to contractual inefficiencies or the need to confront distortionary special interests. Moreover, good institutions may permit a more 
rapid response of the services sector itself, enhancing the capacity to absorb workers from the adjusting downstream sectors. If so, such mechanisms may reduce the social costs of adjustment by manufacturing industries (a 'substitution' effect of economic governance). On the other hand, good institutions may complement policy reforms by helping to attract better quality services (and services providers) into the country (see Beverelli et al., 2015). More efficient services inputs are likely to help domestic manufacturing to specialize and expand the scale of production. ${ }^{15}$ This would result in a positive employment effect of services reforms (a 'scale' effect of economic governance).

Turning to the role of human capital, if - as suggested by recent empirical studies of services offshoring $^{16}$ - a reform-induced expansion in access to efficient producer services triggers a pattern of skill upgrading at the firm and industry level, reforming countries with more skilled labor (higher human capital) may be able to better match this increase in demand for skilled labor, with a direct positive effect on manufacturing employment. This in turn would support specialisation and scale effects that expand labor demand. Overall, high human capital endowments therefore should be associated with a positive effect of services reforms on employment.

As measures of economic governance we use three variables reported in the Worldwide Governance Indicators Database (World Bank), i.e. regulatory quality, control of corruption and rule of law. ${ }^{17}$ As a proxy for human capital we take the gross enrolment ratio in secondary education for both sexes from the World Development Indicators (World Bank). For each moderating variable $m$ we divide the estimation sample into two subsamples and compute the country-specific average of $m$ across available years, obtaining the variable $\bar{m}$. We then divide all countries in two quantiles (LOW and HIGH), below and above the sample median of $\bar{m}$. For each subsample we estimate both the baseline specification and (for robustness purposes) the baseline model augmented with output and wages. Table 5 present the results.

With respect to the full-sample results (Table 3), the negative employment effect of services reforms appears stronger when estimated for those countries with a lower level of economic governance or human capital (LOW quantile of the $\bar{m}$ distribution). It is also always statistically different from 0 at least at a $10 \%$ significance level. This result is robust to the inclusion of output and wages as additional controls. Conversely, when estimated for the subsamples corresponding to the high governance or high human capital countries (HIGH quantile of the $\bar{m}$ distribution), the effect of services reforms is attenuated in both its magnitude and statistical significance. In particular, the coefficient of cref is always smaller (in negative terms) than the corresponding full-sample estimation and it is statistically different from 0 only for the baseline specification in the case when the moderating variable is the rule of law indicator (column 3 in Panel B). These results suggest that both high levels of economic governance and human capital reduce the negative effect of services policy reforms on manufacturing employment.

The transition economies in our sample comprise two groups, with one set of countries having gone through a process of accession to the EU and another that has not. The set of reforms

\footnotetext{
${ }^{15}$ See Francois (1990).

${ }^{16}$ See for instance Geishecker and Görg (2013).

17 Data on these variables are available for all 24 EBRD countries in our sample for the following years: 1996, 1998, 2000, and 2002-2012.
} 
Table 5: Effect of services reform on manufacturing employment at different levels of economic governance and human capital

\begin{tabular}{|c|c|c|c|c|c|c|c|c|}
\hline \multirow[t]{2}{*}{ Panel A } & \multicolumn{4}{|c|}{$m=$ regulatory quality } & \multicolumn{4}{|c|}{$m=$ control of corruption } \\
\hline & (1) & $(2)$ & (3) & (4) & (5) & (6) & (7) & (8) \\
\hline cref & $\begin{array}{l}-2.338^{*} \\
(1.269)\end{array}$ & $\begin{array}{l}-2.363^{* *} \\
(1.194)\end{array}$ & $\begin{array}{l}-0.598 \\
(0.395)\end{array}$ & $\begin{array}{l}-0.642 \\
(0.440)\end{array}$ & $\begin{array}{l}-2.354^{*} \\
(1.272)\end{array}$ & $\begin{array}{l}-2.399^{* *} \\
(1.196)\end{array}$ & $\begin{array}{l}-0.524 \\
(0.395)\end{array}$ & $\begin{array}{l}-0.563 \\
(0.431)\end{array}$ \\
\hline $\log$ output & & $\begin{array}{l}0.356^{* * *} \\
(0.0310)\end{array}$ & & $\begin{array}{c}0.573^{* * *} \\
(0.0563)\end{array}$ & & $\begin{array}{l}0.357^{* * *} \\
(0.0310)\end{array}$ & & $\begin{array}{l}0.572^{* * *} \\
(0.0562)\end{array}$ \\
\hline log wages & & $\begin{array}{l}-0.323^{* * *} \\
(0.0545)\end{array}$ & & $\begin{array}{l}-0.196^{* *} \\
(0.0863)\end{array}$ & & $\begin{array}{l}-0.323^{* * *} \\
(0.0548)\end{array}$ & & $\begin{array}{l}-0.197^{* *} \\
(0.0860)\end{array}$ \\
\hline $\begin{array}{l}\text { Observations } \\
\text { Adjusted } R^{2} \\
\bar{m} \text { quantile }\end{array}$ & $\begin{array}{l}2490 \\
0.103 \\
\text { LOW }\end{array}$ & $\begin{array}{l}2490 \\
0.341 \\
\text { LOW }\end{array}$ & $\begin{array}{c}3004 \\
0.225 \\
\text { HIGH }\end{array}$ & $\begin{array}{c}3004 \\
0.561 \\
\text { HIGH }\end{array}$ & $\begin{array}{l}2475 \\
0.103 \\
\text { LOW }\end{array}$ & $\begin{array}{l}2475 \\
0.342 \\
\text { LOW }\end{array}$ & $\begin{array}{c}3019 \\
0.225 \\
\text { HIGH }\end{array}$ & $\begin{array}{c}3019 \\
0.560 \\
\text { HIGH }\end{array}$ \\
\hline \multirow[t]{2}{*}{ Panel B } & \multicolumn{4}{|c|}{$m=$ rule of law } & \multicolumn{4}{|c|}{$m=$ human capital } \\
\hline & $(1)$ & $(2)$ & $(3)$ & $(4)$ & $(5)$ & $(6)$ & $(7)$ & $(8)$ \\
\hline cref & $\begin{array}{l}-2.570^{*} \\
(1.315)\end{array}$ & $\begin{array}{l}-2.737^{* *} \\
(1.202)\end{array}$ & $\begin{array}{l}-0.782^{*} \\
(0.416)\end{array}$ & $\begin{array}{l}-0.527 \\
(0.468)\end{array}$ & $\begin{array}{l}-1.674^{*} \\
(0.900)\end{array}$ & $\begin{array}{l}-1.552^{*} \\
(0.880)\end{array}$ & $\begin{array}{l}-0.632 \\
(0.569)\end{array}$ & $\begin{array}{l}-0.167 \\
(0.470)\end{array}$ \\
\hline $\log$ output & & $\begin{array}{l}0.344^{* * *} \\
(0.0333)\end{array}$ & & $\begin{array}{l}0.496^{* * *} \\
(0.0451)\end{array}$ & & $\begin{array}{l}0.379^{* * *} \\
(0.0309)\end{array}$ & & $\begin{array}{l}0.478^{* * *} \\
(0.0628)\end{array}$ \\
\hline log wages & & $\begin{array}{l}-0.192^{* * *} \\
(0.0505)\end{array}$ & & $\begin{array}{l}-0.455^{* * *} \\
(0.0741)\end{array}$ & & $\begin{array}{l}-0.311^{\text {*** }} \\
(0.0584)\end{array}$ & & $\begin{array}{l}-0.302^{* * *} \\
(0.0858)\end{array}$ \\
\hline Observations & 2241 & 2241 & 3243 & 3243 & 2364 & 2364 & 3110 & 3110 \\
\hline Adjusted $R^{2}$ & 0.107 & 0.323 & 0.219 & 0.534 & 0.135 & 0.373 & 0.147 & 0.462 \\
\hline $\bar{m}$ quantile & LOW & LOW & HIGH & HIGH & LOW & LOW & HIGH & HIGH \\
\hline
\end{tabular}

required for integration into the $\mathrm{EU}$ is in large part designed to bring the institutional environment of a country closer to EU norms and standards for a wide range of policy areas, including the judiciary, the civil service (bureaucratic efficiency) and the enforcement of competition policy. A priori, accession countries should be characterised by better governance and institutions than non-accession countries, with ambiguous implications for the the impact on the downstream manufacturing employment (as discussed above). Replicating the estimation of the baseline and augmented model on the subsample of countries that acceded to the EU in 2004 we find that the effect of services policy reforms on downstream manufacturing employment, while still negative and significant for the countries that did not join the EU in 2004, becomes statistically non-different from zero in accession countries. ${ }^{18}$ Table 6 presents the results. The policy reforms implied by accession to the EU (for those joining in 2004) are associated with a smaller negative effect on downstream manufacturing employment (columns 3 and 4). This finding is in line with the results from considering the role of economic governance as measured by the indicators of

\footnotetext{
18 The countries that joined the EU in 2004 are Czech Republic, Estonia, Hungary, Latvia, Lithuania, Poland, Slovakia and Slovenia. Including in the accession group the countries that joined the EU in subsequent stages, i.e. Bulgaria (2007), Croatia (2013) and Romania (2007), does not change the results.
} 
regulatory quality, control of corruption and rule of law.

Table 6: Effect of services reform on manufacturing employment in 2004 EU accession countries

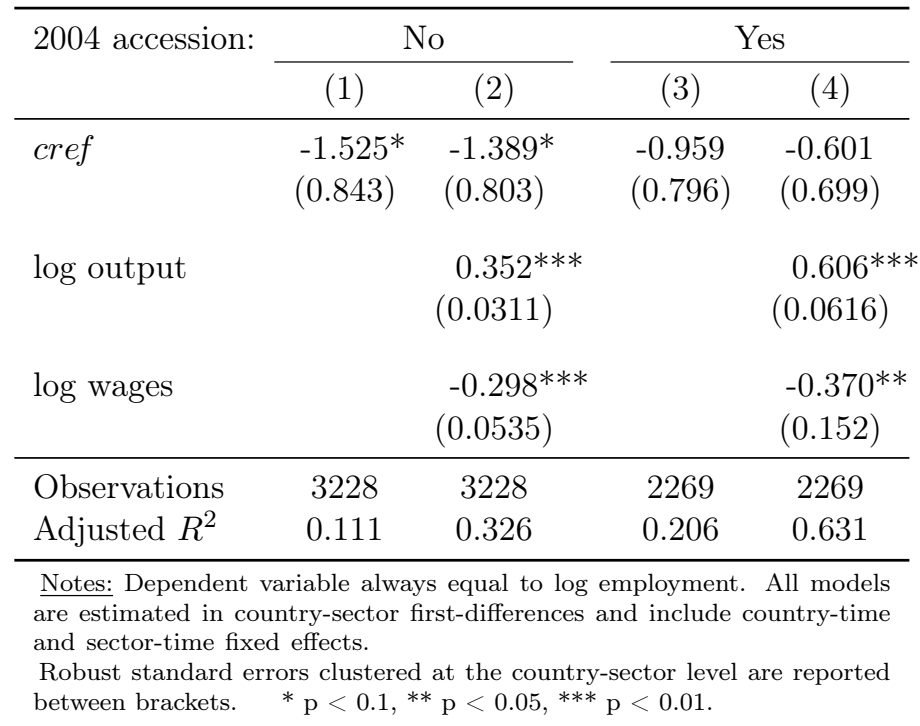

\subsubsection{Stages of the transition process}

An important factor that may have an impact on the estimation of the effect of services reforms on downstream employment is the general transition process in the economies in our sample. In particular, it is reasonable to assume that the initial stages of the transition processes involving large scale changes in the economic environment will swamp any potential positive downstream scale effect from access to (more) efficient services inputs. As has been documented in the literature, transition economies underwent "transformational recessions" (Kornai, 1994; da Rocha, 2015) that were associated with the breakdown of long-standing relationships and inter-sectoral linkages. If we replicate the analysis by estimating our model separately for the first and second half of the 23 years of our sample, we find that the negative effect of services reform is associated with the early stages of transition. ${ }^{19}$

Table 7 presents estimates for both the baseline equation and the model augmented with output and wages. In the two models corresponding to the first half of our sample (columns 1 and 2 of Table 7), the coefficient of the composite reform indicator is negative, statistically significant and slightly larger in size than is the case using the full-sample. For the second half of the sample period (columns 3 and 4 ) the coefficient remains negative but is smaller in magnitude and loses statistical significance.

\subsection{Heterogeneity across services sectors}

We now relax the assumption, implicit in the construction of our composite reform indicator in (3.1), that the impact of policy reforms is homogeneous across services sectors. To do so we define four sector specific variables as the product of the sector specific policy reform indicator

\footnotetext{
${ }^{19}$ Setting the beginning of the second half at the year 2001 or 2002 does not affect the results.
} 
Table 7: Effect of services reform on manufacturing employment in different time periods

\begin{tabular}{|c|c|c|c|c|}
\hline \multirow[t]{2}{*}{ Period: } & \multicolumn{2}{|c|}{ 1990-2001 } & \multicolumn{2}{|c|}{ 2002-2012 } \\
\hline & (1) & $(2)$ & (3) & (4) \\
\hline cref & $\begin{array}{l}-1.098^{*} \\
(0.572)\end{array}$ & $\begin{array}{l}-1.095^{* *} \\
(0.541)\end{array}$ & $\begin{array}{c}-0.411 \\
(0.913)\end{array}$ & $\begin{array}{l}-0.138 \\
(0.867)\end{array}$ \\
\hline $\log$ output & & $\begin{array}{c}0.418^{* * * *} \\
(0.0455)\end{array}$ & & $\begin{array}{l}0.426^{* * *} \\
(0.0442)\end{array}$ \\
\hline log wages & & $\begin{array}{l}-0.247^{* * *} \\
(0.0549)\end{array}$ & & $\begin{array}{l}-0.391^{* * *} \\
(0.0759)\end{array}$ \\
\hline Observations & 2357 & 2357 & 3143 & 3143 \\
\hline Adjusted $R^{2}$ & 0.131 & 0.402 & 0.120 & 0.403 \\
\hline
\end{tabular}

with the corresponding vector of input-output weights. Formally, for each services sector $s$ we define

$$
\text { cref } f_{\text {scit }}=R E F_{\text {sct }} \times w_{s i}
$$

Columns 1-4 of Table 8 report the estimation results when each of these sector-specific indicators is used to replace the aggregate variable cref.

Table 8: Heterogeneity across services sectors and the role of utilities

\begin{tabular}{|c|c|c|c|c|c|}
\hline & \multicolumn{5}{|c|}{ Dep var: log employment } \\
\hline & (1) & $(2)$ & $(3)$ & $(4)$ & $(5)$ \\
\hline cref $f_{\text {utilities }}$ & $\begin{array}{l}-0.832^{*} \\
(0.481)\end{array}$ & & & & \\
\hline$c r e f_{\text {tranport }}$ & & $\begin{array}{l}-0.353 \\
(0.291)\end{array}$ & & & \\
\hline$c r e f_{\text {telecom }}$ & & & $\begin{array}{l}0.0596 \\
(0.238)\end{array}$ & & \\
\hline creffinance & & & & $\begin{array}{c}0.118 \\
(1.018)\end{array}$ & \\
\hline cref $\mathrm{w} /$ out utilities & & & & & $\begin{array}{l}-0.367 \\
(0.339)\end{array}$ \\
\hline Control for output and wages & Yes & Yes & Yes & Yes & Yes \\
\hline Observations & 5500 & 5500 & 5500 & 5500 & 5500 \\
\hline Adjusted $R^{2}$ & 0.406 & 0.405 & 0.405 & 0.405 & 0.405 \\
\hline
\end{tabular}

The only sector-specific policy reform indicator for which the estimated coefficient remains significantly negative is that of utilities (column 1). For transport services (in column 2) the magnitude of the estimate is reduced (in negative terms) and statistical significance is absent at the stan- 
dard levels. Moving to telecommunication (column 3) and financial services (column 4) the sign of the coefficient becomes positive even though not statistically significant. To further explore the role of utilities we construct a version of cref that accounts only for reforms in transport, telecommunications and financial services. The last column of Table 8 shows that when utilities are excluded from the construction of the aggregate composite reform indicator the magnitude of the estimated coefficient is reduced by more than a half with respect to its value in Table 3 and statistical significance decreases below the $10 \%$ threshold.

The results presented in Table 8 suggest that policy reforms targeting electricity, water and waste water related services (utilities) are particularly important for the negative downstream employment effect of services reforms. These are sectors where low values of the EBRD reform indicator reflect monopoly/State ownership and therefore most likely non cost-reflective tariffs (prices), cross-subsidization and soft budget constraints. As a result, policy reforms to introduce commercial pressures may increase services input costs for downstream manufacturing sectors (see Gray, 1995; Freund and Wallich, 1997; Stern and Davis, 1998, for detailed discussions of utilities markets reforms in transition economies). ${ }^{20}$ These results suggest that the overall negative impact on downstream employment is likely to be partly driven by the effects of reforms in the utilities sector on energy-intensive manufacturing sectors.

\subsection{Lagged effects of services reforms}

In this section we investigate the linkages between services reforms and manufacturing employment beyond the instantaneous impact estimated in Table 3. It is plausible that such intersectoral relationships - from upstream producer services to downstream manufacturing employment - would be active and evolve for more than one year. In order to test for the existence of non-contemporaneous effects of service reforms on downstream employment we include several lags of cref. Table 9 presents the results. The point estimates are negative for the contemporaneous change and the first lag and then turn positive. This suggests that the cumulated effect over time might be less negative than what our previous estimates suggested. However we note that the coefficients on lag values are very imprecisely estimated and always associated with p-values above $10 \%$. We also remark that the contemporaneous effect becomes more negative when the lag values are included and that it remains rather stable, showing that the coefficient is robust to the inclusion of lags. Overall we find little support for the notion that longer run effects of policy reforms offset short-run negative impacts on manufacturing employment.

\footnotetext{
${ }^{20}$ While consistent time series data for energy producer prices in our sample of countries are not available before 2007, non-systematic evidence reported in various EBRD Transition Reports reveals a pattern of rising energy and utility prices associated with transition. EBRD (1996) notes that energy prices charged to producers in 1994 were relatively close to those in the EU for those economies that were already at an advanced stage of transition (primarily Eastern European countries and the Baltics), while they remained significantly lower in countries that were still at an early stage of transition (mainly CIS countries).
} 
Table 9: Lagged effects of reforms

\begin{tabular}{|c|c|c|}
\hline & \multicolumn{2}{|c|}{ Dep var: log employment } \\
\hline & (1) & $(2)$ \\
\hline cref & $\begin{array}{l}-1.419^{* *} \\
(0.573)\end{array}$ & $\begin{array}{l}-1.119^{* *} \\
(0.551)\end{array}$ \\
\hline $\operatorname{cref}(t-1)$ & $\begin{array}{l}-0.155 \\
(0.536)\end{array}$ & $\begin{array}{l}-0.379 \\
(0.483)\end{array}$ \\
\hline $\operatorname{cref}(t-2)$ & $\begin{array}{c}0.174 \\
(0.443)\end{array}$ & $\begin{array}{c}0.382 \\
(0.444)\end{array}$ \\
\hline $\operatorname{cref}(t-3)$ & $\begin{array}{c}0.142 \\
(0.412)\end{array}$ & $\begin{array}{c}0.514 \\
(0.351)\end{array}$ \\
\hline Control for output and wages & No & Yes \\
\hline Observations & 5113 & 5113 \\
\hline Adjusted $R^{2}$ & 0.129 & 0.405 \\
\hline
\end{tabular}

\subsection{Services reforms and productivity}

A negative effect on manufacturing employment is consistent with the general result found in the literature cited previously that restrictive services trade policies have adverse effects on productivity of downstream firms and industries. To put our negative employment finding into context, we assess the effect of services reforms on manufacturing productivity in our sample of countries. We rely on the baseline model specified in (3.2) using a measure of productivity as dependent variable. The main potential sources of endogeneity are, mutatis mutandis, analogous to those discussed in Section 3. While we continue to use the US I-O coefficients to generate input intensity measures to minimise reverse causality issues, we do not include any additional control varying at the country-sector-time level. Our assumption is that the relevant variation in the key determinants of productivity such as R\&D intensity is driven by either long-run characteristics (factor endowments, economic geography) or by shocks at the country or industry level (technology, political economy dynamics, etc.) and, therefore, is controlled for by the fixed effects. $^{21}$

Our first measure of productivity is the natural logarithm of value added per employee (labor productivity). This measure has the advantage of limiting the extent to which the sample size is reduced (a decrease in the number of observations of some 20\%). However, as this is a rather rough and limited proxy for productivity, we also construct a measure of total factor productivity (TFP) using standard accounting techniques. We use a Cobb-Douglas model, such

\footnotetext{
${ }^{21}$ The validity of this identification strategy is confirmed by the stability of the estimates for the employment model when moving from the baseline specification to that featuring country-sector-time controls (log output and log wages). A similar approach is adopted in Blonigen (2015) who uses a less demanding version of this empirical model (not including sector-time fixed effects) to investigate the impact of industrial policy in the steel sector on downstream sectors export competitiveness.
} 
that $\log T F P_{c i t}=\log V A_{c i t}-a \log L_{c i t}-(1-a) \log K_{c i t}$, where $V A$ denotes real value added; ${ }^{22}$ $a$ is the sectoral share parameter set equal to $2 / 3$ (as in Cipollina et al., 2012); $L$ and $K$ are respectively employment and the real capital stock. Following Levchenko et al. (2009), the series for capital is constructed using the standard inventory method, where the capital stock in year $t$ is given by $K_{c i t}=(1-d) K_{c i(t-1)}+I_{c i t}$ with $I$ real investment, the depreciation rate $d$ set equal to 0.08 and the initial level of capital stock given by $K_{c i 0}=I_{c i 0} / d .^{23}$ The resulting TFP measure improves upon value added per worker as proxy for productivity. However it entails a significant reduction in the size of the estimation sample. ${ }^{24}$

The results reported in Table 10 indicate a positive effect of services sector reforms on downstream productivity. The magnitude of the positive coefficient in the model for labor productivity (column 1 of Table 10) is about twice that of the negative coefficient in the employment model (Table 3, column 4). This no doubt reflects a mechanical increase in labor productivity that is the counterpart of the reduction in the level of employment.

Table 10: Effect of services reform on manufacturing productivity

\begin{tabular}{|c|c|c|}
\hline \multirow[t]{2}{*}{ Dep var: } & log labor prod & $\log$ TFP \\
\hline & (1) & $(2)$ \\
\hline cref & $\begin{array}{l}1.796^{* * *} \\
(0.675)\end{array}$ & $\begin{array}{c}0.690^{* *} \\
(0.347)\end{array}$ \\
\hline Observations & 4420 & 2198 \\
\hline Adjusted $R^{2}$ & 0.200 & 0.128 \\
\hline $\begin{array}{l}\text { Notes: All moc } \\
\text { differences anc } \\
\text { fixed effects. } \\
\text { country-sector } \\
{ }^{*} \mathrm{p}<0.1,{ }^{* *}\end{array}$ & $\begin{array}{l}\text { e estimated in co } \\
\text { ude country-time } \\
\text { ust standard error } \\
\text { are reported betw } \\
05,{ }^{* * *} \text { p }<0.01 \text {. }\end{array}$ & $\begin{array}{l}\text { ctor first- } \\
\text { ector-time } \\
\text { red at the } \\
\text { ckets. }\end{array}$ \\
\hline
\end{tabular}

The positive sign and the statistical significance of the productivity effect is confirmed by the estimated cref coefficient in the TFP model (Table 10, column 2). ${ }^{25}$ The magnitude of this coefficient implies a sector-specific increase in TFP, following an increase by one standard deviation in all services reform indicators, from $3.33 \%$ to $15.11 \%$. The complete list of TFP effects is given in Table 11.

More generally, these results suggest that, even if services reforms do not trigger a net increase in employment in manufacturing sectors, downstream manufacturing productivity unambiguously benefits from pro competitive policy reforms in producer service sectors.

\footnotetext{
${ }^{22}$ Real value added is obtained by deflating the UNIDO value added series in US dollars by the (output-side) price level for the US with reference year equal to 2005. We use price data from the Penn World Table, version 8.1 (see Feenstra et al., 2015).

${ }^{23}$ As in Beverelli et al. (2015) we take $I_{c i 0}$ as the first non-missing datapoint in the real investment series starting from the 1960s. The series of real investment is constructed by deflating the UNIDO investment series with the (capital formation) price levels reported in the Penn World Table, version 8.1.

${ }^{24}$ This is due to the limited coverage of investment data for the countries and sectors in our sample.

${ }^{25}$ Beverelli et al. (2015) show that the quality of governance institutions impacts on the downstream productivity effects of services trade policy. The estimation sample for model 2 in Table 10 covers 17 countries including some with weak or fragile governance institutions such as Albania, Azerbaijan, Georgia and Mongolia. This makes the positive effect result fairly general and not completely driven by the average quality of economic governance in the subsample.
} 
Table 11: TFP effect of one standard deviation increase in the reform indicator by manufacturing sector

\begin{tabular}{lc}
\hline Manufacturing sector (ISIC rev.3) & $\% \Delta T F P$ \\
\hline Office, accounting and computing machinery (30) & 3.33 \\
Radio, television and communication equipment (32) & 3.70 \\
Medical, precision and optical instruments (33) & 4.32 \\
Other transport equipment (35) & 4.73 \\
Electrical machinery and apparatus n.e.c (31) & 4.81 \\
Motor vehicles, trailers and semi-trailers (34) & 4.93 \\
Machinery and equipment n.e.c (29) & 5.04 \\
Food products, beverages and tobacco (15,16) & 5.51 \\
Manufacturing n.e.c; recycling (36,37) & 5.55 \\
Textiles, textile products, leather and footwear (17-19) & 5.61 \\
Fabricated metal products except machinery and equipment (28) & 6.15 \\
Wood and products of wood and cork (20) & 6.56 \\
Pulp, paper, paper products, printing and publishing (21,22) & 7.66 \\
Rubber and plastics products (25) & 8.90 \\
Chemicals and chemical products (24) & 8.99 \\
Basic metals (27) & 10.33 \\
Coke, refined petroleum products and nuclear fuel (23) & 14.82 \\
Other non-metallic mineral products (26) & 15.11 \\
\hline
\end{tabular}

Notes: ISIC rev.3, 2 digits classification in parenthesis.

\subsection{Further robustness checks}

The robustness of the negative employment effect of our composite services reform indicator to alternative measures of services input intensity can be assessed by replacing the US I-O coefficients with coefficients derived from the US Leontief inverse matrix. These capture, beyond the direct upstream-downstream connections, also the set of indirect relationships linking two sectors at any position in the supply chain. ${ }^{26}$ Columns 1 and 2 of Table 12 show that taking these indirect linkages into account still results in a negative and statistically significant coefficient for the composite reform index cref. This holds for both our baseline specification and the model augmented with output and wages. The use of Leontief coefficients increases the magnitude of the estimates by between 50 and $75 \%$ compared to those reported in Table 3 . This is consistent with a higher degree of input intensity (both direct and indirect) embedded in the Leontief weights.

To assess the validity of our identification assumption about the representativeness of US social accounting matrix and its capacity to capture the technological linkages between sectors rather than US-specific shocks we build an alternative version of the composite reform indicator using input-output coefficients derived from country-specific social accounting matrices. Conditioning on data availability limitations which significantly reduce the estimation sample,${ }^{27}$ the estimates in columns 3-6 of Table 12 confirm the negative and statistically significant employment effect of services reforms. This holds across both specifications and types of input-output coefficients.

\footnotetext{
${ }^{26}$ See Appendix B for the derivation of different input-output coefficients.

${ }^{27}$ Country-specific matrices from OECD STAN database are available for only 11 of the 24 countries in our full sample: Bulgaria, Czech Republic, Estonia, Hungary, Latvia, Lithuania, Poland, Romania, Slovakia, Slovenia and Turkey. We choose the mid 2000s as a reference period to maximize country coverage.
} 
The magnitude of the effects is consistent with the estimates using US as a reference country: in case of the specification with output and wages, the use of country-specific weights increases (in negative terms) the coefficient on cref by $15 \%$.

Table 12: Alternative services input intensity measures

\begin{tabular}{|c|c|c|c|c|c|c|}
\hline \multirow[t]{2}{*}{ IO weights in cref: } & \multicolumn{2}{|c|}{ US leontief } & \multicolumn{2}{|c|}{ country specific (tech) } & \multicolumn{2}{|c|}{ country specific (leont) } \\
\hline & (1) & (2) & (3) & (4) & (5) & (6) \\
\hline cref & $\begin{array}{l}-1.473^{* *} \\
(0.696)\end{array}$ & $\begin{array}{l}-1.532^{* *} \\
(0.662)\end{array}$ & $\begin{array}{l}-1.306^{* * *} \\
(0.363)\end{array}$ & $\begin{array}{l}-1.014^{* * *} \\
(0.312)\end{array}$ & $\begin{array}{l}-1.360^{* * * *} \\
(0.486)\end{array}$ & $\begin{array}{l}-1.424^{* * *} \\
(0.481)\end{array}$ \\
\hline $\log$ ouput & & $\begin{array}{c}0.418^{* * *} \\
(0.0311)\end{array}$ & & $\begin{array}{c}0.577^{* * *} \\
(0.0569)\end{array}$ & & $\begin{array}{c}0.578^{* * *} \\
(0.0568)\end{array}$ \\
\hline log wages & & $\begin{array}{l}-0.328^{* * *} \\
(0.0543)\end{array}$ & & $\begin{array}{l}-0.194^{* *} \\
(0.0877)\end{array}$ & & $\begin{array}{l}-0.194^{* *} \\
(0.0876)\end{array}$ \\
\hline Observations & 5500 & 5500 & 2959 & 2959 & 2959 & 2959 \\
\hline Adjusted $R^{2}$ & 0.135 & 0.406 & 0.222 & 0.562 & 0.222 & 0.562 \\
\hline
\end{tabular}

Notes: Dependent variable always equal to log employment. All models are estimated in country-sector first-differences and include country-time and sector-time fixed effects. Robust standard errors clustered at the country-sector level are reported between brackets. $* \mathrm{p}<0.1,{ }^{* *} \mathrm{p}<0.05, * * * \mathrm{p}<0.01$.

Finally, to check whether our baseline results reflect the excessive influence of the country with the highest or lowest average policy reform value across services sectors (respectively Estonia and Bosnia Herzegovina) we alternatively exclude these countries from the estimation sample and assess how the resulting coefficients are affected. We replicate this exercise excluding one-by-one the sectors with the highest and lowest average value of services input use intensity (respectively manufacturing of non metallic mineral products - ISIC code 26 - and manufacturing of office, accounting and computing machinery, ISIC code 30). As shown in Table 13, the coefficients are robust to the exclusion of these extreme cases, that is, they remain negative and significant at the $5 \%$ level.

Table 13: Influential observations

\begin{tabular}{|c|c|c|}
\hline \multirow[t]{2}{*}{ Omitting influential } & countries & sectors \\
\hline & (1) & $(2)$ \\
\hline cref & $\begin{array}{l}-0.964^{* *} \\
(0.475)\end{array}$ & $\begin{array}{l}-1.438^{* *} \\
(0.659)\end{array}$ \\
\hline Control for output and wage & Yes & Yes \\
\hline Observations & 5290 & 4883 \\
\hline Adjusted $R^{2}$ & 0.391 & 0.429 \\
\hline \multicolumn{3}{|c|}{$\begin{array}{l}\text { Notes: Dependent variable always equal to log employment. All } \\
\text { models are estimated in country-sector first-differences and include } \\
\text { country-time and sector-time fixed effects. Influential countries are } \\
\text { defined as those with the highest and lowest average value of pol- } \\
\text { icy reform indicators across services sectors (respectively Estonia } \\
\text { and Bosnia Herzegovina). Influential sectors are defined as those } \\
\text { with the highest and lowest average value of services input intensity } \\
\text { across services sectors (respectively manufacturing of non metallic } \\
\text { mineral products - ISIC code } 26 \text { - and manufacturing of office, ac- } \\
\text { counting and computing machinery, ISIC code } 30 \text { ). } \\
\text { Robust standard errors clustered at the country-sector level are re- } \\
\text { ported between brackets. } \quad * \text { p }<0.1, * * p<0.05, * * * p<0.01 \text {. }\end{array}$} \\
\hline
\end{tabular}




\section{Concluding remarks}

In this paper we analyze the effect of services policy reforms on downstream employment in manufacturing. This is a subject of general interest that has not been the focus of much crosscountry empirical research, in part because of lack of time series data on applied service sector policies for many countries. The performance of services sectors can have a significant impact on industries that use services as intermediate inputs. Our results complement the literature identifying positive productivity effects of pro-competitive services policy reforms by documenting the existence of a negative relationship between services policy reforms that move countries towards what are regarded to be best practices and employment in downstream manufacturing industries. We also find that the negative effect on manufacturing employment is mitigated or disappears for countries with high levels of economic governance and human capital, pointing to the importance of the broader business environment and investment climate in moderating the impacts of services policy reforms.

Our analysis is based on a panel of sector-level data for 24 transition economies for the 1990-2012 period. The focus on these countries is motivated in large part by the availability of annual time series data on applied services policies. The transition economies that are the focus of analysis are in many ways exceptional, but for our purposes a key feature of these countries is that the EBRD has been compiling services sector-specific policy indicators for over two decades. While this has benefits in permitting the use of a large battery of fixed effects, which in principle should do much to control for the idiosyncratic features of these countries, the potential downside is that our results, notwithstanding the controls, may not have general validity.

Whatever the case may be in this regard, our results suggest that services policy reforms are one factor explaining the declining share of manufacturing that occurred in the transition economies. Overall service sector employment grew rapidly following the demise of central planning. This structural transformation of the transition economies is not surprising, of course, given the distorted initial conditions that prevailed in these countries. Employment statistics for these countries show that the share of total employment in manufacturing initially declined for the group as a whole, and then gradually increased (see Figure 1 above). Moving towards best practice services policies was associated with an economically significant reduction of manufacturing employment, helping to explain the observed trend in sectoral employment shares. Our results suggest that at the aggregate level the potential positive scale effect of better access to services for downstream manufacturing industries is more than offset by incentives to outsource non-core tasks and the associated reduction in the workforce employed in manufacturing. 


\section{References}

Amiti, Mary and Shang-Jin Wei, "Fear of service outsourcing: is it justified?," Economic Policy, April 2005, 20 (42), 308-347.

_ and _ , "Service Offshoring, Productivity and Employment: Evidence from the US," CEPR Discussion Paper 5475, C.E.P.R. Discussion Papers January 2006.

Arnold, Jens Matthias, Aaditya Mattoo, and Gaia Narciso, "Services Inputs and Firm Productivity in Sub-Saharan Africa: Evidence from Firm-Level Data," Journal of African Economies, 2008, 17 (4), 578-599.

_, Beata Javorcik, and Aaditya Mattoo, "Does Services Liberalization Benefit Manufacturing Firms? Evidence from the Czech Republic," Journal of International Economics, 2011, 85 (1), $136-146$.

_, _, and _ , "Services Reform and Manufacturing Performance. Evidence from India," Economic Journal, 2016, 126 (590), 1-39.

Barone, Guglielmo and Federico Cingano, "Service Regulation and Growth: Evidence from OECD Countries," Economic Journal, 2011, 121 (555), 931-957.

Bas, Maria, "Does services liberalization affect manufacturing firms' export performance? Evidence from India," Journal of Comparative Economics, 2014, 42 (3), 569 - 589.

BenYishay, Ariel and Pauline Grosjean, "Initial endowments and economic reform in 27 post-socialist countries," Journal of Comparative Economics, 2014, 42 (4), 892 - 906.

Beverelli, Cosimo, Matteo Fiorini, and Bernard Hoekman, "Services Trade Restrictiveness and Manufacturing Productivity: The Role of Institutions," CEPR Discussion Paper September 2015.

Blonigen, Bruce A., "Industrial Policy and Downstream Export Performance," Economic Journal, 2015.

Bourlès, Renaud, Gilbert Cette, Jimmy Lopez, Jacques Mairesse, and Giuseppe Nicoletti, "Do Product Market Regulations in Upstream Sectors Curb Productivity Growth? Panel Data Evidence for OECD Countries," Review of Economics and Statistics, December 2013, 95 (5), 1750-1768.

Cipollina, Maria, Giorgia Giovannetti, Filomena Pietrovito, and Alberto F. Pozzolo, "FDI and Growth: What Cross-country Industry Data Say," The World Economy, 2012, 35, 1599-1629.

da Rocha, Bruno T., "Let the markets begin: The interplay between free prices and privatisation in early transition," Journal of Comparative Economics, 2015, 43 (2), 350 - 370.

Duggan, Victor, Sjamsu Rahardja, and Gonzalo Varela, "Service Sector Reform and Manufacturing Productivity. Evidence from Indonesia," 2013. World Bank Policy Research Working Paper No. 6349. 
EBRD, Transition Report 1996. Infrastructure and Savings, London, UK: European Bank for Reconstruction and Development, 1996.

Falcetti, Elisabetta, Tatiana Lysenko, and Peter Sanfey, "Reforms and growth in transition: Re-examining the evidence," Journal of Comparative Economics, 2006, 34 (3), 421 445 .

Feenstra, Robert C., Robert Inklaar, and Marcel P. Timmer, "The Next Generation of the Penn World Table," American Economic Review, October 2015, 105 (10), 3150-82.

Fernandes, Ana and Caroline Paunov, "Foreign Direct Investment in Services and Manufacturing Productivity: Evidence for Chile," Journal of Development Economics, 2011, 97 (2), $305-321$.

Forlani, Emanuele, "Competition in the service sector and the performances of manufacturing firms: does liberalization matter?," 2012. CESifo Working Paper No. 2942.

Francois, Joseph F., "Producer Services, Scale, and the Division of Labor," Oxford Economic Papers, 1990, 42 (4), 715-729.

Freund, Caroline and Christine Wallich, "Public Sector Price Reforms in Transition Economies: Who Gains? Who Loses? The Case of Household Energy Prices in Poland," Economic Development and Cultural Change, 1997, 46 (1), 35-59.

Geishecker, Ingo and Holger Görg, "Services offshoring and wages: evidence from micro data," Oxford Economic Papers, 2013, 65 (1), 124-146.

Görg, Holger and Aoife Hanley, "International Outsourcing and Productivity: Evidence from Plant Level Data," Research Paper Series: Globalisation, Productivity and Technology. Research Paper No. 20/2003 2003.

_, , , and Eric Strobl, "Les effets de productivité de la sous-traitance internationale: résultats à partir de données au niveau des établissements.," Canadian Journal of Economics/Revue canadienne d'économique, 2008, 41 (2), 670-688.

Gray, Dale, "Reforming the energy sector in transition economies," World Bank Discussion Papers, August 1995.

Hoekman, Bernard and Ben Shepherd, "Services Productivity, Trade Policy and Manufacturing Exports," The World Economy, 2015, pp. n/a-n/a.

Kornai, János, "Transformational Recession: The Main Causes," Journal of Comparative Economics, 1994, 19 (1), $39-63$.

Levchenko, Andrei A., Romain Rancière, and Mathias Thoenig, "Growth and risk at the industry level: The real effects of financial liberalization," Journal of Development Economics, 2009, 89 (2), 210-222.

Milberg, William and Deborah Winkler, "Economic insecurity in the new wave of globalization: offshoring and the labor share under varieties of capitalism," International Review of Applied Economics, 2010, 24 (3), 285-308. 
_ and _ , "Financialisation and the dynamics of offshoring in the USA," Cambridge Journal of Economics, 2010, 34 (2), 275-293.

_ and _ , "Offshoring and the Labour Share in Germany and the US: The Role of Different Policy Regimes," World Economics, December 2015, 16 (4).

Rajan, Raghuram G and Luigi Zingales, "Financial Dependence and Growth," American Economic Review, 1998, 88 (3), 559-586.

Rodrik, Dani, "Unconditional Convergence in Manufacturing," Quarterly Journal of Economics, 2013, 128 (1), 165-204.

Roland, Gérard and Thierry Verdier, "Transition and the output fall," Economics of Transition, 1999, 7 (1), 1-28.

Schöller, Deborah, "Service Offshoring and the Demand for Less-Skilled Labor: Evidence from Germany," Hohenheimer Diskussionsbeiträge No. 287/2007 2007.

Stern, Jon and Junior R. Davis, "Economic reform of the electricity industries of Central and Eastern Europe," Economics of Transition, 1998, 6 (2), 427-460.

Winkler, Deborah, "Services Offshoring and its Impact on Productivity and Employment: Evidence from Germany, 1995-2006," The World Economy, December 2010, 33 (12), 16721701.

Wright, Greg C., "Revisiting the employment impact of offshoring," European Economic Review, 2014, 66, $63-83$. 


\section{Appendices}

\section{A Appendix tables}

Table A-1: Variables used in the empirical analysis

\begin{tabular}{|c|c|}
\hline Variable & Description and source \\
\hline \multicolumn{2}{|c|}{ Country - manufacturing sector - time level } \\
\hline$C R E F_{c i t}$ & $\begin{array}{l}\text { Composite reform indicator. It captures the exposure of manufacturing sector } i \text { in } \\
\text { country } c \text { at time } t \text { to the policy reforms targeting services sectors in country } c \text { at } \\
\text { time } t \text {. Variable defined in equation (3.1). Source: policy reform data from Tran- } \\
\text { sition Indicators Database, European Bank for Reconstruction and Development } \\
\text { (EBRD). Input intensity data from US IO Table (mid 1990s) from OECD STAN } \\
\text { IO Database }\end{array}$ \\
\hline cref $_{c i t}$ & $\begin{array}{l}\text { Normalised version of } C R E F_{c i t} \text {, varying between } 0 \text { and } 1 . \text { It is computed as } \\
c r e f_{c i t}=\left(C R E F_{c i t}-\min \left\{C R E F_{c i t}\right\}\right) /\left(\max \left\{C R E F_{c i t}\right\}-\min \left\{C R E F_{c i t}\right\}\right)\end{array}$ \\
\hline$l_{\text {cit }}$ & $\begin{array}{l}\text { Log of employment in manufacturing sector } i \text { in country } c \text { at time } t \text {. Version } \\
\text { without log denoted with } L \text {. Source: UNIDO INDSTAT4, Rev. } 3 .\end{array}$ \\
\hline $\log$ output $_{c i t}$ & $\begin{array}{l}\text { Log of output in manufacturing sector } i \text { in country } c \text { at time } t \text {. Output expressed } \\
\text { in current USD. Source: UNIDO INDSTAT4, Rev. } 3 .\end{array}$ \\
\hline $\log _{\text {wages }}$ cit & $\begin{array}{l}\text { Log of individual wages in manufacturing sector } i \text { in country } c \text { at time } t \text {. Wages } \\
\text { expressed in current USD. Source: UNIDO INDSTAT4, Rev. } 3 \text {. }\end{array}$ \\
\hline $\log$ imports $_{c i t}$ & $\begin{array}{l}\text { Log of gross imports of manufacturing sector } i \text { in country } c \text { at time } t \text {. Imports } \\
\text { expressed in current USD (thousands). Source: World Bank WITS. }\end{array}$ \\
\hline$y_{c i t}$ & $\begin{array}{l}\text { Log of labor productivity (value added per worker) in manufacturing sector } i \text { in } \\
\text { country } c \text { at time } t \text {. Value added expressed in current USD. Source: UNIDO } \\
\text { INDSTAT4, Rev. } 3 \text {. }\end{array}$ \\
\hline $\log T F P_{c i t}$ & $\begin{array}{l}\text { Log of total factor productivity in manufacturing sector } i \text { in country } c \text { at time } \\
t . \log T F P_{\text {cit }} \text { is defined in Section 5.5. Source: value added, total employment, } \\
\text { investment from UNIDO INDSTAT4, Rev. 3. Prices from Penn World Table } 8.1\end{array}$ \\
\hline \multicolumn{2}{|c|}{ Services sector - country - manufacturing sector level } \\
\hline$w_{\text {sci,mid } 2000 s}$ & $\begin{array}{l}\text { Input intensity of services } s \text { into manufacturing sector } i \text {. It is equal to the corre- } \\
\text { sponding technical coefficient from the input-output matrix of country } c \text { for the } \\
\text { mid 2000s. Alternative measures (Leontief coefficients) are described in Appendix } \\
\text { B. Source: OECD STAN IO Database. }\end{array}$ \\
\hline \multicolumn{2}{|c|}{ Country - services sector - time level } \\
\hline$R E F_{\text {sct }}$ & $\begin{array}{l}\text { Policy reform indicator for services sector } s \text { in country } c \text { at time } t \text {. For detailed } \\
\text { construction of the variable see Section } 4 \text {. Source: Transition Indicator Database, } \\
\text { EBRD. }\end{array}$ \\
\hline \multicolumn{2}{|c|}{ Manufacturing sector - services sector level } \\
\hline$w_{s, U S, i, m i d 90 s}$ & $\begin{array}{l}\text { Input intensity of services } s \text { into manufacturing sector } i \text {. In the benchmark esti- } \\
\text { mation it is equal to the corresponding technical coefficient from the US input- } \\
\text { output matrix for the mid 1990s. Alternative measures are described in Appendix } \\
\text { B. Source: OECD STAN IO Database. }\end{array}$ \\
\hline \multicolumn{2}{|l|}{ Country level } \\
\hline $\bar{m}_{c}$ & $\begin{array}{l}\text { Variable used to divide the sample in Section } 5.2 \text {. It is constructed as the average } \\
\text { across time of } m_{c t} \text { which, case by case, captures the quality of one governance in- } \\
\text { stitution (either regulatory quality, rule of law or control of corruption) or human } \\
\text { capital measured as the gross enrolment ratio in secondary education (average } \\
\text { across both sexes). Source: Governance Institutions from the Worldwide Gover- } \\
\text { nance Indicator, World Bank. Human capital from World Development Indicators, } \\
\text { World Bank }\end{array}$ \\
\hline
\end{tabular}


Table A-2: Countries and sectors in the empirical analysis

\begin{tabular}{llccc}
\hline Countries & & & \multicolumn{2}{l}{ Sectors } \\
\cline { 1 - 2 } Albania & Latvia & & $15-16$ & 31 \\
Azerbaijan & Lithuania & & $17-19$ & 32 \\
Belarus & Mongolia & & 20 & 33 \\
Bosnia and Herzegovina & Poland & $21-22$ & 34 \\
Bulgaria & Republic of Moldova & & 23 & 35 \\
Croatia & Romania & & 24 & $36-37$ \\
Czech Republic & Russian Federation & & 25 & \\
Estonia & Slovakia & & 26 & \\
Georgia & Slovenia & & 27 & \\
Hungary & Republic of Macedonia & & 28 & \\
Kazakhstan & Turkey & & 29 & \\
Kyrgyzstan & Ukraine & 30 & \\
\hline
\end{tabular}

Notes: Sector numbers follow ISIC Rev. 3, 2 digits classification 


\section{B Input-output coefficients}

\section{Technical coefficients}

Technical coefficients are derived from the intermediate demand matrix $M$ (the first quadrant of a social accounting matrix). $M$ is a square matrix of dimension $n$ where rows - indexed by $r$ - are the supplying industries (domestic and international) and the columns - $k$ - the using (domestic) industries. The number of industries in $M$ is equal to $n$. A generic element $m_{r k}$ of $M$ represents the cost borne by sector $k$ for the output produced by sector $r$ (as domestic production plus imported foreign production) and used as intermediate input into $k$. Technical coefficients are the elements of the square matrix $A$, defined as:

$$
A \equiv Y M
$$

where $Y$ is an $n$-dimension square matrix where the main diagonal includes the inverse output of each industry and all the other elements are equal to zero. For each services-manufacturing sector pair $(s, i)$, the technical coefficient is given by the element $a_{s i}$ of matrix $A$ and it measures the cost of the intermediate inputs from services sector $s$ for one dollar of total production of manufacturing sector $i$.

\section{Leontief coefficients}

The alternative measures of input intensity used in the paper are the coefficients derived from the Leontief inverse matrix. The input intensity of services sector $s$ into manufacturing sector $i$ that takes into account all the indirect linkages between the (upstream) supplying and the (downstream) using sector is given by the element $l_{s i}$ of matrix $L$, defined as:

$$
L \equiv V B
$$

where $V$ is a dimension $n$ square matrix of zeros, except along the main diagonal, that includes the value added-output ratios of each industry. $B$ is the Leontief inverse $(I-A)^{-1}$, with $A$ defined in equation (B-1) above. 


\section{Description of the EBRD reform indicators and the indepen- dent variables}

The index ranges from 1 (almost no progress in comparison with a socialist economy) to 4.3 (most advanced implementation of reform agenda) and has been document annually over the 1990-2012 period by the EBRD's chief economist office. Below, we provide a description of the underlying data and how we aggregate them to compute our independent variable. ${ }^{28}$

In order to combine the EBRD database with the OECD STAN data where industries are classified according ISIC rev. 3 (2 digits) we apply the following mapping from EBRD sectors to ISIC: finance to sectors 65,66 and 67 ; telecommunications to sector 64 ; transports to sectors 60,61,62 and 63; utilities to 40 and 41.

We proceed to some aggregations of the different reforms indicators in order to map them to the ISIC rev. 3 classification. The aggregation and the different original indicators are detailed below:

1. Finance: Our indicators is the simple average of the banking and non-banking reform indicators.

- Banking reform and interest rate liberalisation: 1 corresponds to minimum progress beyond establishment of a two-tier system; 4.3 corresponds to full convergence of banking laws and regulations with BIS standards.

- Securities markets and non-bank financial institutions: 1 corresponds to minimum progress; 4.3 corresponds to full convergence of securities laws and regulations with IOSCO standards.

2. Telecommunications: Our indicator is equal to the original one provided by EBRD:

- Telecommunications: 1 implies that there has been little progress in commercialisation and regulation (minimal private sector involvement, strong political interference in management decisions, low tariffs, with extensive cross-subsidisation etc.); 4.3 corresponds to an effective regulation through an independent entity.

3. Transports: Our indicator is the simple average of the railways and roads reform indicators.

- Railways: 1 corresponds to a situation where railways are managed by a monolithic government structure, with few commercial freedoms and no private sector involvement and extensive cross-subsidisation; 4.3 corresponds to railways fully being commercialised, with separate internal profit centres for freight and passenger services and involvement of private companies in the freight business and maintenance.

- Roads: 1 corresponds to minimal degree of decentralisation and no commercialisation. All regulatory, road management and resource allocation functions centralised at ministerial level; 4.3 corresponds to a fully decentralization with road maintenance competitively awarded to private companies.

4. Utilities: Our indicator is the simple average of the electricity and water reform indicators.

- Electricity: 1 corresponds to the power sector operating as government department, with little competitive pressure; 4.3 corresponds to tariffs being driven by costs and providing adequate incentives for efficiency improvements.

\footnotetext{
${ }^{28}$ Description of the underlying data comes from the EBRD's website: http://www.ebrd.com/cs/Satellite?c=Content\&cid=1395237866249\&d=\&pagename=EBRD\%2FContent\%2FContentLayout
} 
- Water: 1 corresponds to minimal degree of decentralisation and no commercialisation with no financial autonomy capacity at municipal level; 4.3 implies that water utilities fully decentralised and commercialised. 


\section{Author contacts:}

\section{Matteo Fiorini}

Global Governance Programme

Robert Schuman Centre for Advanced Studies, EUI

Villa Schifanoia

Via Boccaccio, 121

50133 Firenze

Italy

E-mail: matteo.fiorini@eui.eu

\section{Bernard Hoekman}

Global Governance Programme

Robert Schuman Centre for Advanced Studies, EUI

Villa Schifanoia

Via Boccaccio, 121

50133 Firenze

Italy

Email: bernard.hoekman@eui.eu

\section{Clément Malgouyres}

Directorate Microeconomic and Structural Studies

Banque de France

41-1391 RECFIN

F-75049 Paris Cedex 01

Email: Clément Malgouyres cmalgouyres@gmail.com 